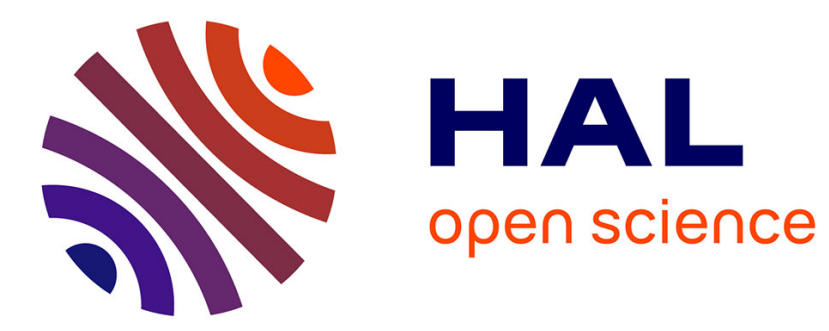

\title{
Innovation in virtual social networks: the widespread of new electronic currencies and the emergence of a new category of entrepreneurs
}

\author{
Olivier Hueber
}

\section{- To cite this version:}

Olivier Hueber. Innovation in virtual social networks: the widespread of new electronic currencies and the emergence of a new category of entrepreneurs. Intenational Journal of Transitions and Innovation Systems, 2011, 1 (2), pp.163-174. 10.1504/IJTIS.2011.039623 . hal-00589937

\section{HAL Id: hal-00589937 https://hal.science/hal-00589937}

Submitted on 28 Oct 2019

HAL is a multi-disciplinary open access archive for the deposit and dissemination of scientific research documents, whether they are published or not. The documents may come from teaching and research institutions in France or abroad, or from public or private research centers.
L'archive ouverte pluridisciplinaire HAL, est destinée au dépôt et à la diffusion de documents scientifiques de niveau recherche, publiés ou non, émanant des établissements d'enseignement et de recherche français ou étrangers, des laboratoires publics ou privés. 


\title{
Innovation in virtual social networks: the widespread of new electronic currencies and the emergence of a new category of entrepreneurs
}

\author{
Olivier Hueber \\ University of Nice - Sophia Antipolis, \\ GREDEG - CNRS (UMR n 6227), \\ 250, rue Albert Einstein, 06560 Valbonne, France \\ E-mail: olivier.hueber@unice.fr
}

\begin{abstract}
The internet network hosts an increasing number of large synthetic worlds. These virtual worlds exhibit most of the characters we associate with the real world like interpersonal relationships, economic transactions, production of goods and services, political institutions...Inside these synthetic worlds, new economic behaviours can be studied and new entrepreneurs emerge. By focusing on the widespread of new private electronic currencies, this paper shows first the main benefits for e-money users of entering in a community of payments. Second, the economic behaviour of electronic money (e-money) users and the network externalities effects are studied. Thirdly, the phenomenon of the emergence of a new category of entrepreneurs specialised in e-money creation and the regulation of a new monetary regime are exposed.
\end{abstract}

Keywords: social networks; e-money; virtual worlds; monetary regime; Veblen good; clearing house, digital money, Linden dollar.

Reference to this paper should be made as follows: Hueber, O. (xxxx) 'Innovation in virtual social networks: the widespread of new electronic currencies and the emergence of a new category of entrepreneurs', Int. J. Transitions and Innovation Systems, Vol. X, No. Y, pp.000-000.

Biographical notes: Olivier Hueber is an Associate Professor of Economics at the University of Nice - Sophia Antipolis, France. In addition, he is a Researcher at GREDEG - CNRS (UMR n 6227). His researches are in monetary theory by focusing on electronic money and, entrepreneurship in transition countries. He is also an author of a textbook for undergraduate French students devoted to general economics.

\section{Introduction}

The internet network makes possible the emergence of private electronic money (e-money) which originates outside any government and outside any official banking system. For instance, the Linden Dollar in Second Life, the WoWGold in the online game World of Warcraft or the loyalty points like Smiles or Miles and more can be considered as digital bearer money. The communities of e-money users are communities of practices which adopt specific decisions, routines and behaviours. The financial and banking innovations are introduced by new entrepreneurs principally from virtual social networks. 
The aim of this paper is threefold. First, it presents the most recent financial and banking innovations permitted by the news digital cash issued by virtual social networks. Such a part will allow us to highlight new forms of Entrepreneurship like new e-money providers or new digital cash's wholesalers. Second, this paper studies interactions of e-money users, which emerge from virtual social networks. These interactions are characterised especially by increasing returns to scale, bandwagon effects and, ostentatious consumption. Moreover, innovations in e-money make necessary new institutions and new forms of coordination and cooperation. Third, faced with the emergence of numerous entrepreneurs specialised in e-money, we expose how setting-up a new coordination in the aim of organising properly and securing the private e-money circulation in virtual worlds. This paper ends by a concrete proposition of the setting-up of an automatic clearing house devoted to organise the interaction between numerous e-money users' networks.

\section{E-money and virtual social networks}

The internet network makes possible the emergence of new communities of payment using e-money. E-money is broadly defined as an electronic store of monetary value on a technical device that may be widely used for making payments without necessarily involving bank accounts in the transaction, but acting as a prepaid bearer instrument. Communities of e-money have several characteristics. The first one is the anonymity. It can be possible to transfer funds anonymously with the paypal system. Nowadays, over 210 millions of accounts are open in the paypal website (http://www.paypal.com). It is possible to receive money while remaining anonymous. A simple e-mail address is sufficient for selling and buying. PayPal lets shop without sharing financial information. Obviously, it is easier to hide money from the government by using the paypal system. However, if you have a non-verified status on your paypal bank account you are limited in your payments. It is impossible to pay more than $1500 €$. Such a limit of payment can be crossed by creating, still anonymously numerous paypal accounts. Anonymity in transaction is something that buyers and sellers often want. Forms of e-money can provide anonymity but still rely on trust between the parties.

In the UK, it is possible to buy a prepaid Mastercard called Cashplus without informing your bank. A simple driving licence or a passport is sufficient to buy the Cashplus prepaid card. With such a card, the buyer is not anonymous but, like any paper banknote, the money can circulate apart from the banking system ${ }^{1}$.

Either Paypal or Mastercard (with Cashplus) are companies enabling to circulate public e-money that is e-money linked to the official interbank system. Beside the public e-money, numerous private electronic currencies are set up by new entrepreneurs like Philip Rosedale the creator of the virtual world Second Life or Blizzard the creator of World of Warcraft.

Also, the second characteristic of the new communities of e-money users relies on the capacity of creating temporarily private money. A truly private, e-money originates outside the government and outside the banking system.

In the Europe, the regulation 2002-2013 of 21 November 2002 prevented anyone to issue e-money outside the European interbank system ${ }^{2}$. However, the development of the e-commerce is so rapid than the temptation to use anonymous ways of payment is, for many reasons, very strong for many e-buyers and e-sellers. 
On that subject, the Second Life network users, is enlightening (see http://www.secondlife.com). Second Life has its own currency called Linden. On any given day people are using it to conduct transactions. People can cash Lindens out of the game on the Lindex. Several online resources allow residents of Second Life to convert Linden Dollars into US dollars and vice-versa. Rates fluctuate based on supply and demand, but over the last few years they have remained fairly stable at approximately 270 Linden dollars (L\$) to the US dollar. It is also possible to make money in Second Life but such as money is not generated by private players of the game. All the money circulating in Second Life, around 300,000 US dollars everyday on average, comes originally from the 'real' central banks. Nevertheless, players earning Linden dollars during the game avoid temporarily the official taxation on profits.

Living in an economy, where different monies coexist, and forces people to adapt every aspect of their economic activities to this new environment. The most routine daily transactions have to be organised differently. As explained by Heymann and Leijonhufvud (1995), "Money is not a refrigerator. The picture of money as a service-producing asset is incomplete without a look at transactions practices". Admittedly, with the e-money the transaction costs decrease but new practices of transactions also appear. The monetary regime tends to be parcelled out by different communities of payment. By monetary regime, we adopt the Heymann-Leijonhufvud definition that is on the one hand, a system of expectations on the part of the public that governs their decision and, on the other, that pattern of behaviour on the part of the policy-making authorities that sustains these expectations ${ }^{3}$. The monetary regimes forms a crucial part of the environment in which both the public and the authorities have to make their decisions. This conception of the monetary regime concept postulates that economic agents, faced with incomplete information, cannot all arrive at the same inferences in a given situation or have not the same confidence in the inference they draw. An e-money user, like any linden dollar's user, makes decisions without be able to evaluate properly its purchasing power. For instance, the exchange rate Linden/US Dollar cannot be fully understood.

The economy operates with different currencies, which each one used in different types of transactions. Wages are paid in domestic money and households convert them partly in different e-monies or quasi e-monies. Different communities of payment threaten social institutions and arrangements existing in a united monetary regime.

The emergence of different communities of payment menaces the public character of the money. Money can be considerate as a public good. On this subject, Wieser (1927) clearly regarded money as one of the founding institutions of social economy. Money is an institution which has social responsibilities. Money ownership must follow the same rules for anyone. With the digital bearer money, networks of money users are developing apart from banks and others networks. Digital bearer money is like cash and can be transferred person-to-person without going through a bank or PayPal account. The Digital bearer money creates injustice toward those for practical, legal or financial reasons cannot access it. Moreover, a major change in the nature of money would have significant unintended consequences. For instance, the advantages for criminals and tax evaders could be considerable.

Creating a private e-money in a virtual world permits to entrepreneurs to gain the loyalty of their customers. The 'miles and mores' of the Lufthansa Company or the 'A-Club miles' of the Accor group are both loyalty programs ${ }^{4}$. Admittedly the loyalty points are far from being considered as fully electronic currencies in the sense that these 
point do not fulfil the traditional three functions of the money (unit of account, mean of payment and store of value). The loyalty points do not have a general purchasing power in a monetary regime. With 'Smiles' for instance, you can buy a huge number of goods or services either in virtual or real worlds but you cannot buy all the goods and services. An increasing number of entrepreneurs (like for instance LoyaltyMatch) permit to their customers to convert their loyalty points/miles gained through many different loyalty programs all around the world in official cash.

For the moment, the footbridges between the various communities do not exist. Nevertheless, it is enlightening to make a comparison between Smiles and Maximiles.

Smiles or Maximiles are like points, much as the airlines' frequent flyer miles. They are now used as rewards for visiting hundreds websites. But as more sites are added, these points tend to become world's virtual currency on the internet and can be assimilated as Digital bearer money ${ }^{5}$. Regarding to the Maximiles provider, it is possible to obtain Maximiles without using euros. The more you are visiting or buying good or services on the Maximiles online network, the more you obtain Maximiles. You can also buy Maximiles online for buying goods or services only available in the Maximiles' shop network ${ }^{6}$.

The communities of both Paypal banking services and Linden Dollars users are growing very fast. One important consequence results in the decrease in demand for central banks and consequently the decrease of central bank seigniorage revenue (see, Nsouli and Fullenkamp, 2004). The central banks make large income from issuing paper banknotes, which are non-interest bearing central banks liabilities. The decrease of seigniorage revenues may cause that central banks can not cover their operation costs. As seigniorage revenues are one of the most significant income sources of national treasury at the same time, it can be also stated that there will be a decrease in the income of treasury.

The decrease in money demand due to the spreading of the e-money can be studied by using the Baumol-Tobin framework. Such a framework direct attention to the transaction costs of moving in and out money substitutes. The 'shoe-leather' metaphor - the real costs of too many trips to the bank or broker- stems directly from it. The internet e-money permit a reduction in transaction costs (the 'shoe leather cost'). Consequently, on one side, the interest elasticity of money demand increase and on the other side there is a permanent decrease in money demand.

\section{E-money and economic behaviour}

The various e-money networks communities, like the Linden dollars case raise new questions. Traditionally, games worlds are completely distinct from the real world. In Second Life, a virtual world, many virtual objects - like ideas, software, surveys - bought or sold during the game by virtual avatars are directly marketable in the real world. For instance, it is possible to make and enquiry, an opinion pool or any marketing test in the Second Life world and selling in central money, the results of these surveys in the real world. Nowadays, most of the biggest international firms are active in Second Life. The borders between the Second Life virtual world and the real world are increasingly fuzzy. On an economic point of view, this opacity complicates the rational calculus of the price vector. In the general neoclassical theory inherited of Walras, Jevons and Menger, the fixation on a price rely on the private utility. In Second Life, the players buy or sell 
virtual objects at a price based on ostentatious criteria. For instance, you do not buy a virtual coat with linden dollars to avoid a cold in winter but for showing yourself and showing your richness in Linden Dollars. Therefore, goods have not a private utility for agents but a social utility.

The works of Thorstein Veblen (1857-1929) are helpful to understand the price determination mechanisms in virtual worlds like the Second Life world. Veblen (1899) argues that economic life is driven not by notions of utility. He defined conspicuous consumption as the waste of money by people to display a higher status than others. The conspicuous consumption term has a very popular catchphrase which is 'Keeping up with the Joneses'. Such a expression refers to the desire to be seen as being as good as one's contemporaries using the comparative benchmarks of social caste or the accumulation of material goods. By Social class, Veblen refers to the hierarchical distinctions between individuals or groups in societies or cultures. Failing to 'keep up with the Joneses' is perceived as demonstrating to others socio-economic or cultural inferiority. The conspicuous consumption term takes root in The Theory of Moral Sentiments of Adam Smith. Adam Smith (1759) acknowledged that economic agents value wealth not only for the goods and services that it procure to them, but also for the impression that it makes on others. Veblen analyses displays of wealth as status signals, but Smith proposes a different explanation. According to Smith, the consumer is naturally more disposed to show his richness than his poverty ${ }^{7}$. Following Smith, John Stuart Mill (1848) observes that many goods are bought for the reputation they procure in regard to the opinion ${ }^{8}$.

Like Smith and Mill, Veblen recognises the importance of consumption not for its own sake but what it signals about the consumer. Originally, the conspicuous consumption term was used by Veblen to depict the behavioural characteristic of the nouveau riche, a new class that emerged in the 19th century. Afterwards, the signification of this term was extended to economic agents whose consumption patterns are driven by status seeking rather than their substantial needs. From Veblen works on conspicuous consumption, Paul Nystrom (1928) theorised a philosophy of futility which encompassed the emergence addictive or narcissistic behaviours provoked by consumerism. For Veblen, the conspicuous leisure is a waste of time by people to give themselves higher status. He asserts that humans are not rational, utility-seeking people who try to maximise their pleasure but are completely irrational creatures that run after social status. Reading Veblen works by taking into consideration what occurs in Second Life is very enlightening. In the economic virtual worlds, the different communities of e-money users behave with an emulation attitude. The term emulation is proposed by Veblen to illustrate the permanent run after the social status. The avatars attempt to mimic the more respected members of their group in order to gain more status for themselves. Such a mimetic process can be studied by using the institutional isomorphic change described by DiMaggio and Powel (1983). Moreover, the emulation attitude modifies the mechanism of price determination. In Second Life, many goods are Veblen goods. Commodities are Veblen goods, by definition, if people's preference for buying them increases as a direct function of their price.

Some types of high-status goods in Second Life or in World of Warcraft, such as expensive virtual clothes, are Veblen goods, in that decreasing their prices decreases people's preference for buying them because they are no longer perceived as exclusive or high status products. Similarly, a price increase may increase that high status and perception of exclusivity, thereby making the good further preferable. For instance, 
decreasing the price of the land decreases people's preference for buying it because it is no longer perceived as exclusive or high status products.

The Veblen goods introduce anomalies in the general theory of supply and demand in microeconomics. Among these anomalies, we can observe the snob effect which increases the demand for virtual goods or services because they have a high economic value, but low practical value. In virtual worlds, the Veblen goods introduce another anomaly called bandwagon effect (see Leibenstein, 1950). There is a bandwagon effect when the preference for goods increases as the number of people buying them increases. The bandwagon effect disturbs the normal results of the theory of supply and demand, which assumes that consumers make buying decisions solely based on price and their own personal preference.

As pointed out by Arthur (1989), such an effect introduces networks externalities by increasing returns to adoption. Networks externalities can be found in any network because they provoke a positive feedback. The more the network increases, the more the network is attractive for new users.

Network effects become significant after a certain subscription percentage has been achieved, called critical mass. By studying different electronic purses schemes, Clark (2005) found that the most successful networks tend to have the following characteristics: a captive audience that drives critical mass, such as those found in the transportation industry or government sector; an affordable cost structure relative to other payment instruments; compelling incentives to consumers and merchants; and a technology that is well tested and that addresses standard issues before the rollout. Admittedly, the Second Life community, as any virtual network, is characterised by this positive feedback. Moreover, positive feedbacks can be found inside the network because most a goods in Second life are Veblen goods.

For Veblen, social change can be analysed as a process of institutional coordination and transformation. Any human community, like the Second life community, may be viewed as an economic mechanism. Such an economic mechanism is closely linked to the material environment in which the human community lives. According to Veblen, the economic and social behaviours are impeded from cultural rigidities. Observing the behaviour and mind sets of the avatars in the Second Life Community confirm the assertion of Veblen. The Second Life world allow an agent to choose what kind of avatar she or he will live in, allowing a person with any kind of real body to inhabit a completely different body in the virtual world. As studied by Edward Castronova (2003), the emergence of avatar-mediated living raises both positive and normative questions. Logically, the main aim of creating an avatar in Second Life is to live a 'Second Life' that is, a life which can be completely different of the life in the real world. Surprisingly, most of the avatars are a clone of its owners. For instance, if a man with brown hairs creates his own avatar on Second Life, he will choose a masculine brown hairs avatar. The cultural rigidities on the real life pass through the virtual Second Life (see, Cogerino 2009).

After having studied the economic features of new virtual worlds based on electronic currency or different forms private quasimoney (Section 2) and after having described how the e-money users behave in these different virtual world (Section 3), it become necessary to draw coordination mechanisms to organise the increasing number of new public and private electronic currencies (Section 4). 


\section{An automatic clearing house for e-money's users}

For the moment, the footbridges between the various communities do not exist. For example, consumers with Linden Dollars can not buy goods or services in the game World of Warcraft, or in networks of Smiles. It becomes necessary to bridge the gap between official monetary regimes (like the Euro regime) and virtual monetary regimes (like the Linden dollar regime). By a virtual monetary regime, we mean a monetary regime which exclusively includes online transactions realised with a private virtual electronic currency. The setting up of an automated clearing house (ACH) is a prerequisite for coordinating different virtual monetary regimes. Such ACH must fulfil two distinctive missions. First the ACH must allow any member of any e-money network to buy or sell goods or services with any others e-money users. Second, the ACH must permit to any member of a virtual monetary regime to exchange its private e-money for a public currency (like the Euro or the US dollar).

\subsection{Inside the Virtual monetary regime}

Imagine two virtual worlds (A and B) which have their own private virtual money (VMA and VMB). In order to buy a goods or services, you can only use VMA in world A and $\mathrm{VMB}$ in world $\mathrm{B}$. An individual has always the choice to consume various combinations of world A and world B virtual goods bundles. In economics, this is an allocation problem.

Suppose that a same basket of goods or services $\mathrm{G}$ can be bought in world A in VMA or in World B in WMB. The price of this basket of goods (PG) is 2 WMA in world A and $4 \mathrm{VMB}$ in world $\mathrm{B}$. In extension, we can assume that the exchange rate between WMA and WMB is 0.5 (WMA/WMB $=1 / 2$ ). On a fixed period of time, people from virtual world A demand to their bank (Bank A) $100 \mathrm{VMB}$ (i.e., $50 \mathrm{VMA}$ ) to buy goods or services in world B and people from virtual world B demand to their bank (Bank B) 300 WMA (i.e., $600 \mathrm{VMB}$ ) for acquiring goods or services in world A. An ACH oversees several payments networks in virtual worlds.

The balance sheet of the clearing house is the following:

Table 1 Automated clearing house

\begin{tabular}{|c|c|c|c|}
\hline \multicolumn{2}{|l|}{ Assets } & \multicolumn{2}{|c|}{ Liabilities } \\
\hline \multicolumn{2}{|c|}{ Refinancing $=300 \mathrm{VMA}$} & \multicolumn{2}{|c|}{ anknotes for Bank A = $100 \mathrm{VMB}$} \\
\hline \multicolumn{2}{|c|}{ Refinancing $=100 \mathrm{VMB}$} & tual Banknotes for & ank B = 300 VMA \\
\hline \multicolumn{2}{|l|}{ Bank A } & \multicolumn{2}{|c|}{ Bank B } \\
\hline Assets & Liabilities & Assets & Liabilities \\
\hline Loans 50 VMA & Bank account 50 VMA & Loans $600 \mathrm{VMB}$ & $\begin{array}{c}\text { Bank Account } 600 \\
\text { VMB }\end{array}$ \\
\hline Banknotes 100 & Refinancing $=100$ & Bank notes 300 & Refinancing $=300$ \\
\hline
\end{tabular}


In such a monetary regime, Bank A can only issue VMA and Bank B can only issue VMB. The clearing house can issue, on a basis of a simple conversion, banknotes (like e-money) of any bank of the monetary regime in return of any other deposit. Therefore, the clearing house organises and supervises a virtual monetary regime (see Figure 1).

Figure 1 Virtual monetary regime ${ }^{9}$

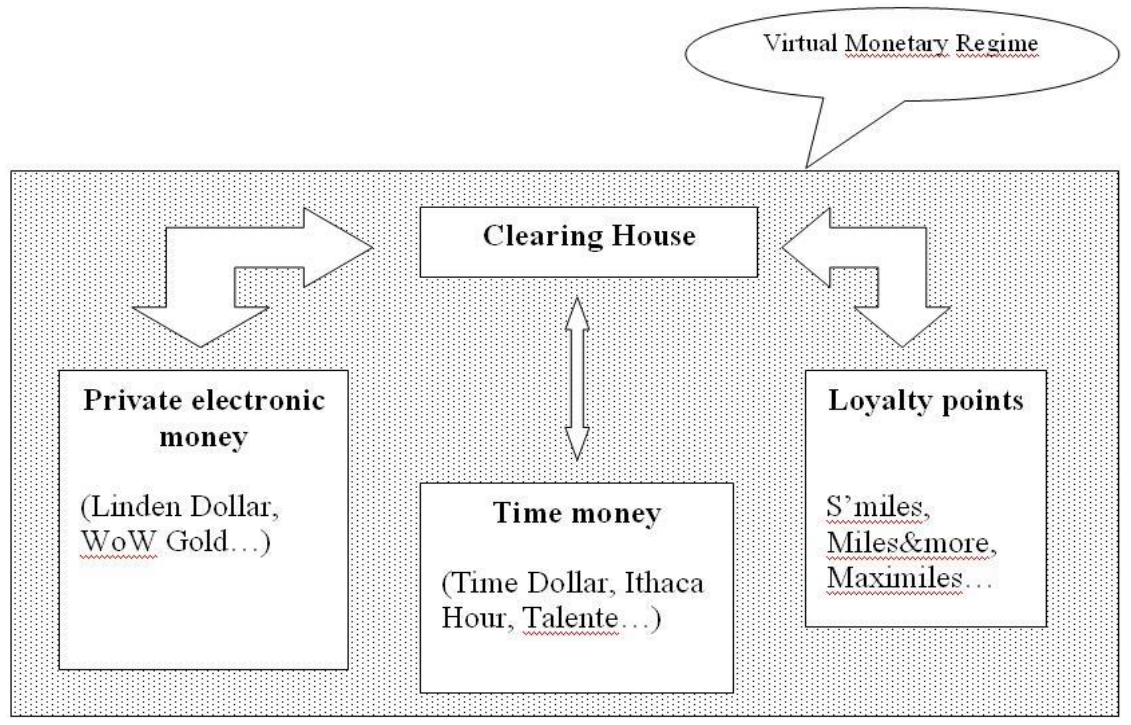

Using the Leijonhufvud's concept of monetary regime, we consider that a virtual monetary regime forms the economic environment in which private money users, private banks and the clearing house have to make their decisions ${ }^{10}$. The ACH has to establish many institutional arrangements in order to ensure the reliability of interactions between the numerous e-money suppliers (public or private). Therefore, if for some reason or other the monetary regime undergoes a vicious circle of unreliable interactions then the $\mathrm{ACH}$ must put in application new rules concerning the behaviour of both the private and public agents. These new rules must specify precisely the kinds of transactions the monetary authorities can execute. The role of the ACH has to be understood for all the economic agents. To gain and conserve a good degree of reputation, the $\mathrm{ACH}$ must be constraint by tight monetary rules. If the confidence is not present, then strict and credible legal constraints must be introduced to support expectations of both the public and the private sector.

\subsection{Outside the monetary regime}

Economics agents must have the possibility to convert their wealth from virtual money to real public money (as US dollar or Euro). The role of bridging the gap between the real world and the virtual world is devoted to the ACH. The ACH could give to any virtual bank some special drawing rights which are based on a standard of measure like the gold standard. This proposal comes to partially reinvent sixty years after, the 'bancor' of 
Keynes. Keynes wanted to create an international currency. In Keynes's clearing house, central banks would pay subscriptions in gold and then would borrow in 'bancor' an international currency that it could use only to settle debits against another central bank. Once created, bancor balances could not be redeemed on demand at the clearing house, but would be cancelled automatically when the borrowing country repaid its credits. Bancor thus was to be a form of 'outside' money that would circulate in a closed economy limited to central banks.

Figure 2 Virtual gold creation by an automated clearing house (ACH)

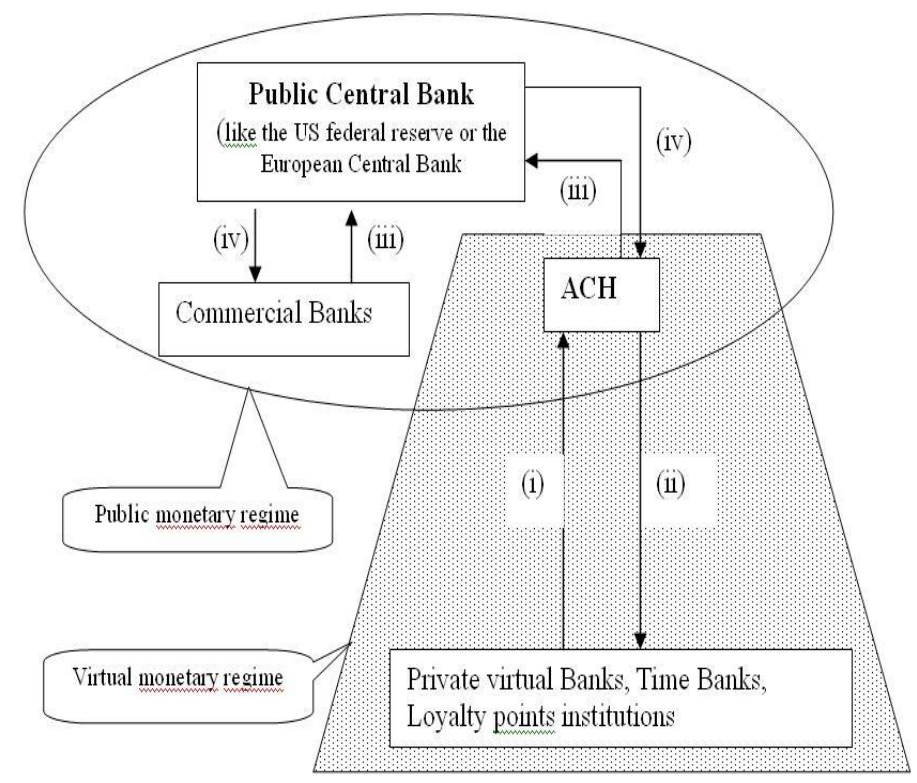

Notes: (i) Gold or equivalent in any public money

(ii) Virtual gold unit (for instance an once of Gold or social gold by Google)
(iii) Reserves in public money or in gold

(iv) Refinancing

By extension of the bancor system imaginated by Keynes, virtual private banks would pay to the ACH a subscription in gold and then would borrow virtual gold units (Figure 2). Then they use such a virtual gold units with real banks to obtain 'real money' (public money as US dollar or Euro) ${ }^{11}$. Faced with a multiplicity of new electronic currencies, the buyers and the sellers are suffering of a lack of information. The development of the e-commerce is hindered by a confusing virtual environment which seems more like a jungle. Therefore, a measure of standard of value is required. Such a measure has to be simple and clearly understood by all the e-money users. Once the standard of value found, still exists a remaining economic problem which has to be solved, namely the anchor of this standard of value. Proposing a virtual gold ounce as a yardstick is a solution both clear and practicable. Nevertheless, at this point of our research, there is a problem to solve which lies in the choice or the no choice of an anchor for this virtual gold ounce. The solution of attaching an underlying asset for the virtual gold ounce 
reinforces the credibility of the virtual monetary regime regulated by the ACH. Moreover, the underlying asset helps the system to cross the bridge between the virtual worlds and the real world. However, anchoring the virtual gold ounce with a real underlying asset exposes the virtual monetary regime to the hazards of the variation of the value of this asset in the real world. For instance a fixed parity with the value of the gold barrel is non-sense. Even a fixed parity with the real value of the ounce gold is not obvious by itself. It could be a priori possible to give to the ounce of virtual gold an intrinsic value like for the euro or the US dollar. Therefore, the value of the ounce of virtual gold could fluctuate according to the law of the supply and demand. Some additional researches have to be done to estimate the reliability of such a solution.

\section{Conclusions}

The need to set up an interbank system in the aim of making reliable and credible the exchange mechanisms between an increasing number of new public and private electronic currencies becomes urgent. By using the concept of monetary regime derived from Leijonhufvud's works, we observe that at the present time, the market in which private electronic currencies or nearly electronic currencies are in circulation are hindered by a huge lack of coordination mechanisms. Moreover, specific characteristics inherent to the network structures of e-money have to be taken into account.

The communities of e-money users are communities of practice which adopts specific decisions, routines and behaviours. These communities can temporarily move away from the official monetary regime regulated by central banks. Moreover, the classical analysis of price setting behaviour based on the private utility maximisation rule is somewhat unsuited. The bandwagon effect, the Veblen effect and the increasing return of adoption effect are the three main characteristics of the e-money markets.

With e-monies, publics or privates, the monetary policy becomes less effective. Quasi e-monies like the Linden dollars provide socially useful services. The central banks should not prevent them to fulfil their social missions. However, central banks should integrate them in the official interbank system both for fiscal reasons and to protect the lawful aspect of the money. Money must not generate exclusion. All the economic agents must have access to all type of goods and all the virtual shopping centres.

In the framework proposed in this paper (see Figure 2), the role of matching the virtual and the real monetary regime is vested to a clearing house. In case of a trust crisis or any economic malfunctioning, the e-money users can easily convert their cash in a certain amount of gold virtual ounce and then if the crisis lasts they still have the opportunity to change the gold ounce in real currencies like the US dollar or the Euro. Therefore, additional studies have to be done in the aim of define with accuracy the functioning of each stakeholder of the new virtual monetary regime that we propose to build. 


\section{References}

Arthur, W.B. (1989) 'Competing technologies, increasing returns and lock-in by historical events', The Economic Journal, Vol. 99, pp.116-131.

Castronova, E. (2001) Virtual Worlds: A First-Hand Account of Market and Society on the Cyberian Frontier, p.618, CESifo Working Paper.

Castronova, E. (2003) Theory of the Avatar, CESifo Working Paper No. 863, Munich.

Clark, C.L. (2005) 'Shopping without cash: the emergence of the e-purse', Economic Perspectives, pp.34-51, Fourth Quarter.

Cogerino, A. (2009) 'La construction de l'avatar sur Second Life: un jeu de contraintes entre la réalité et la société virtuelle’, Adolescence, No. 69, pp.621-629.

Dimaggio, P.J. and Powell W.W (1983) 'The iron cage revisited: Institutional isomorphism and collective rationality in organizational fields', American Sociological Review, p.48.

Ernstbergerr, P. (2009) Linden Dollar and Virtual Monetary Policy, University of Bayreuth, Working Paper.

Fuchs et al. (2006) Le traité de la Réalité Virtuelle: les Applications de la Réalité Virtuelle, Vol. 4, Ecole des mines de Paris.

Hayek, F.A. (1978) Denationalisation of Money: The Argument Refined, Institute for Economic Affairs, Londres.

Hedström, P. (1998) 'Rational imitation', in Hedström, P. and Swedberg, R. (Eds.): Social Mechanisms, Cambridge University Press, Cambridge.

Heymann, D. and Leijonhufvud, A. (1995) High Inflation, Oxford University Press.

Leibenstein, H. (1950) 'Bandwagon, snob, and Veblen effects in the theory of consumers' demand', Quarterly Journal of Economics, Vol. 64, pp.183-207.

Lietaer, B. and Kennedy, M. (2008) Monnaies Régionales: De Nouvelles Voies vers une Prospérité Durable, Charles Leopold Mayer Editions.

Mill, J.S. (1848) Principles of Political Economy, Longmans, Green and Co., London.

Nsouli, S. and Fullenkamp, C. (2004) 'The regulatory framework for e-banking', Banking, Payments, and ICT Conference, 6-8 June, Beirut, Lebanon.

Nystrom, P. (1928) Economics of Fashion, Ronald Press, New York.

Smith, A. (1759) The Theory of Moral Sentiments, Chap. I. III, p.16, A Millar, London.

Veblen, T. (1899) The Theory of the Leisure Class, Penguin Books.

Weiser, F. (1927) Social Economics, Reprints of Economic Classics, M.A. Kelley, 1967, New York.

\section{Notes}

1 For getting a Cashplus prepaid card in the UK, no credit check, non-bank account or no identity card is required. Moreover, no minimum income or employment is needed.

2 Regulation 2002-2013 of 21 November 2002: French application by the Banque de France Chapter II art 19.4: 'The above-mentioned institutions shall provide the Banque de France with at least an annual report on their activities, stating in particular the total amount of financial liabilities related to outstanding e-money.'

3 See Heymann and Leijonhufvud (1995, p.85).

4 eBay launched in 2010 a new rewards program called eBay Bucks, which allows any eBay buyer who lives in the USA and which is a registered member of the site to earn money from $2 \%$ on most items purchased through the site with PayPal. Consumers can earn 'eBay bucks' on eBay and through his many mobile applications. Users can pay the 'eBay bucks' in purchases on the merchant site. Rewards are accumulated over a period of three months and at Comment [t1]: Author: Please cite the
reference in the text or delete from the list if not required.

Comment [t2]: Author: Please cite the reference in the text or delete from the list if not required.

Comment [t3]: Author: Please cite the reference in the text or delete from the list if not required.

Comment [t4]: Author: Please cite the reference in the text or delete from the list if not required. 
the end of each period, a certificate is issued eBay bucks for consumers, who then have 30 days to exchange their bucks with eBay purchases with PayPal on http://eBay.com.

5 Maximiles and Smiles provide to their members with free rewards in exchange for loyalty points collected by shopping online with some of the UK and France's biggest brands. With these companies, the customers can collect loyalty points for free when they complete surveys, enter competitions, register for services and even respond to emails. Moreover, there's a huge choice of free rewards to spend loyalty points.

6 At the present time the EUR/Maximiles exchange rate is 0.02, i.e., with 1 euro, you can buy online 50 maximiles.

7 Smith, A. (1759) The Theory of Moral Sentiments, Chapter II, "It is because mankind are disposed to sympathise more entirely with our joy than with our sorrow, that we make parade of our riches, and conceal our poverty. Nothing is so mortifying as to be obliged to expose our distress to the view of the public, and to feel, that though our situation is open to the eyes of all mankind, no mortal conceives for us the half of what we suffer."

8 Mill, J.S. (1848) Chapter VI, "a great portion of the expenses of the higher and middle classes in most countries, and the greatest in this, is not incurred for the sake of the pleasure afforded by the things on which the money is spent, but from regard to opinion, and an idea that certain expenses are expected from them, as an appendage of station; and I cannot but think that expenditure of this sort is a most desirable subject of taxation.”

9 Graph one is based largely on Lietaer and Kennedy book's published in 2008 and untitled 'Monnaies Régionales', p.174.

10 See, Heymann and Leijonhufvud (1995, p.39).

11 Google bought in 2010 for \$70M a company called Jambool which operates the Social Gold payment product. Social Gold enables developers to create and manage their own white-labelled virtual currency, to provide an in-app payments experience to their users, and to optimise their virtual economy using analytics. Social Gold powers the virtual currency and payment solutions for thousands of online games and virtual worlds. 